\title{
A Darwinian approach to mine closure and restoration
}

\author{
A.J.M. Baker School of Botany, The University of Melbourne; and Environmental Earth Sciences \\ International Pty Ltd, Australia
}

\begin{abstract}
Mineral wastes, particularly those from ancient metalliferous operations, provide an evolutionary theatre where the long-term impacts of natural selection can be observed on organisms able to colonise an environment where few species can survive. Darwin's vision of 'survival of the fittest' applies dramatically in such extreme environments where metal toxicities may be powerful and clear-cut. Plant materials selected from these sites provide a wealth of pre-adapted genotypes for exploitation in mine site rehabilitation and ecosystem restoration.
\end{abstract}

\section{Introduction}

This year (2009) marks the bicentenary of the birth of Charles Darwin and the 150th anniversary of the publication of his monumental work, 'On the Origin of Species by Means of Natural Selection'. Darwin's ideas have surely changed our outlook on life on Earth and the ramifications of his theory of evolutionary change have impacted increasingly on society and our appreciation of the environment. It is therefore not surprising that these have even extended into operational aspects of the minerals industry (Guardian Environment Network, 2009). Perhaps of more practical application, however, has long been recognition of the role the mine environment can play in the natural selection process of biotic forms adapted for survival in a multiply-stressed environment and how such knowledge can then be exploited in the revegetation and ecological restoration of mining-impacted lands and so frame policies of mine closure.

\section{The mine environment as an evolutionary theatre}

The wastes of mining activities, especially from metalliferous mining, frequently present a substrate inimical to plant establishment and gradual rehabilitation and ecosystem development through biodiversity increase in plant, animal and microbial communities. Ancient mineral workings, many of which are now orphaned or abandoned sites, are frequently the most extreme environments for the processes of natural colonisation to proceed. This is largely because of the ongoing impacts of metal toxicities in addition to other substrate stresses such as poor physical conditions (often leading to drought), nutrient deficiencies and imbalances, salinity, $\mathrm{pH}$ extremes and low organic matter status. Modern extractive operations may present a more 'neutral' but nevertheless degraded environment for ecosystem restoration on mine closure.

Old mine workings and wastes are frequently of a small size and are often isolated in the surrounding landscape. As such, they represent ecological islands usually supporting few colonists. Such sites, however, provide an evolutionary theatre where the forces of natural selection have impacted on the local biota to achieve some degree of ecological restoration. Even the most toxic sites can support a plant cover and here we can truly see evolution in action. On the oldest sites, such as those worked in Roman times in Europe, this cover can be a continuous one and the slow process of natural attenuation has been almost completed. In the 1960s and 1970s the work of the late Professor A.D. Bradshaw and his colleagues at the Universities of Bangor and Liverpool in the United Kingdom, has elegantly demonstrated the importance of the evolution of heavy metal tolerances and tolerances of other stress factors operating on ancient mine workings, especially on populations of grass species common in the surrounding landscapes. Indeed, these populations represent unique genetically-adapted materials in a surrounding 'sea of normality'. 


\section{The speed of evolutionary change}

It is tempting to believe that tolerant populations of plants able to colonise mineral wastes have been present on a long evolutionary timescale as the selective forces of metal toxicities are very powerful and clear-cut: if a plant genotype is not tolerant to the prevailing toxicities, it will be eliminated in one generation. Exposure to such forces can, however, result from high concentration of potentially toxic metals (such as lead, zinc, cadmium and copper) in soils resulting from weathering of minerals and dispersion from superficial orebodies and outcrops on a geological timescale. These ancient and largely pristine areas may support unique metallophyte vegetation of high biodiversity significance (Baker and Whiting, 2008). However, tolerant plants populations have been demonstrated on datable mine sites from Roman times $(\sim 2,000$ years), and also more recent operations from the industrial revolution ( 250 years). Even recent smelter sites in otherwise uncontaminated areas can support metal-tolerant populations. The speed of evolutionary change can thus be far more rapid. Indeed, it can almost be instantaneous in one generation if the necessary genetic variability is present within the plant species gene pool for natural selection to operate and those pressures are applied. However, very few individuals are hence selected and it will be some years for a population to fully develop and the spiral of ecological restoration commence.

\section{$4 \quad$ Exploitation of the effects of natural selection in mine restoration}

The impacts of natural selection have provided the minerals industry with a ready source of pre-adapted materials for potential use in large-scale revegetation programmes and planning for eventual mine closure. Pre-existing populations of plants on mineral sites possess tolerances to the suite of unfavourable substrate characteristics and climatic conditions prevailing. However, the approach has been used only to a limited extent largely due to a lack of commercial quantities of suitable materials and seed resources. An ameliorative approach to mine site restoration has been employed far more than an adaptive one (Tordoff et al., 2000). The pioneering work of Bradshaw's team in developing commercial strains of the temperate grasses Festuca rubra (red fescue) and Agrostis capillaris (bent grass) has provided an excellent template for the research and development activity required to move from field collections to the shelf of the seed merchants. However, there has been little attempt elsewhere to utilise native materials in this way. Global studies clearly indicate the vast resource of naturally-selected biota which exist and await commercial exploitation so why has this not progressed since this seminal work over 40 years ago? It is therefore timely for this question to be addressed by the minerals industry.

\section{Extended references}

Antonovics, J., Bradshaw, A.D. and Turner, R.G. (1971) Heavy metal tolerance in plants, Advances in Ecological Research, Vol. 7, pp. 1-85.

Antonovics, J. (1975) Metal tolerance in plants: perfecting an evolutionary paradigm, In Proceedings of the First International Conference on Heavy Metals in the Environment, 27-31 October 1975, Toronto, Ontario, Canada, pp. $169-186$.

Baker, A.J.M. (1987) Metal tolerance, New Phytologist, Vol. 106 (Suppl.), pp. 93-111.

Baker, A.J.M. and Whiting, S.N. (2008) Metallophytes - a unique biodiversity and biotechnological resource in the care of the minerals industry, In Proceedings of the Third International Seminar on Mine Closure, Mine Closure 2008, A.B. Fourie, M. Tibbett, I.M. Weiersbye, P. Dye (eds), 14-17 October 2008, Johannesburg, South Africa, Australian Centre for Geomechanics, Perth, pp. 13-20.

Bergholm, J. and Steen, E. (1989) Vegetation establishment on a deposit of zinc mine wastes, Environmental Pollution, Vol. 56, pp. 127-144.

Bradshaw, A.D. (1970) Pollution and evolution, New Scientist, Vol. 17, December 1970, pp. 497-500.

Bradshaw, A.D. (1975) The evolution of metal tolerance and its significance for vegetation establishment on metal contaminated sites, In Proceedings of the First International Conference on Heavy Metals in the Environment, 27-31 October 1975, Toronto, Ontario, Canada, pp. 599-622.

Bradshaw, A.D., Humphreys, M.O. and Johnson, M.S. (1978) The value of heavy metal tolerance in the revegetation of metalliferous mine wastes, In Environmental Management of Mineral Wastes, G.T. Goodman and M.J. Chadwick (eds), Sijthoff and Noordhoff International Publishers BV, Alphen aan den Rijn, The Netherlands, pp. 311-334.

Bradshaw, A.D. (1991) The Croonian Lecture, Genostasis and the limits to evolution, Philosophical Transactions of the Royal Society of London, Vol. B 333, pp. 289-305. 
Cooke, J.A. and Johnson, M.S. (2002) Ecological restoration of land with particular reference to the mining of metals and industrial minerals: a review of theory and practice, Environmental Reviews, Vol. 10, pp. 41-71.

Guardian Environment Network (2009) Darwin's lessons for the extractive industry, viewed 3 June 2009, http://www.guardian.co.uk/environment/2009/may/27/network-energy.

Humphreys, M.O. and Bradshaw, A.D. (1976) Genetic potentials for solving problems of soil mineral stress: heavy metal toxicities, In Plant Adaptation to Mineral Stress in Problem Soils, Proceedings of a Workshop, M.J. Wright (ed), Beltsville, Maryland, USA, November 1976, pp. 95-105.

Johnson, M.S. and Bradshaw, A.D. (1977) Prevention of heavy metal pollution from mine wastes by vegetative stabilization, Transactions/Section A of the Institution of Mining and Metallurgy, Vol. 86, pp. 47-55.

Johnson, M.S. and Putwain, P.D. (1981) Restoration of native biotic communities on land disturbed by metalliferous mining, Minerals and the Environment, Vol. 3, pp. 67-85.

Johnson, M. and Tanner, P. (2005) Mine site rehabilitation and ecosystem reconstruction for biodiversity gain, viewed 25 May 2009, http://www.crdi.ca/fr/ev-84055-201-1-DO_TOPIC.html.

McNeilly, T. (1987) Evolutionary lessons from degraded systems, In Restoration Ecology, W.R. Jordan, M.E. Gilpin and J.D. Aber (eds), Cambridge University Press, Cambridge, pp. 271-286.

Smith, R.A.H. and Bradshaw, A.D. (1972) Stabilization of toxic mine wastes by the use of tolerant plant populations, Transactions/Section A of the Institution of Mining and Metallurgy, Vol. 81, pp. 230-237.

Smith, R.A.H. and Bradshaw, A.D. (1979) The use of metal tolerant plant populations for the reclamation of metalliferous wastes, Journal of Applied Ecology, Vol. 16, pp. 595-612.

Tordoff, G.M., Baker, A.J.M. and Willis, A.J. (2000) Current approaches to the revegetation and reclamation of metalliferous mine wastes, Chemosphere, Vol. 41, pp. 219-228.

Williamson, N.A., Johnson, M.S. and Bradshaw, A.D. (1982) Mine Waste Reclamation, The Establishment of Vegetation on Metal Mine Wastes, Mining Journal Books, London, 103 p. 